Published in final edited form as:

Curr Opin Immunol. 2014 June ; 0: 27-33. doi:10.1016/j.coi.2014.01.014.

\title{
Vaccine Immunity against Fungal Infections
}

\author{
Som G. Nanjappa ${ }^{1}$ and Bruce S. Klein ${ }^{1,2,3}$ \\ ${ }^{1}$ Department of Pediatrics, University of Wisconsin School of Medicine and Public Health, \\ University of Wisconsin-Madison, Madison, WI, 53792 \\ 2Department of Internal Medicine, University of Wisconsin School of Medicine and Public Health, \\ University of Wisconsin-Madison, Madison, WI, 53792 \\ ${ }^{3}$ Department of Medical Microbiology and Immunology, University of Wisconsin School of \\ Medicine and Public Health, University of Wisconsin-Madison, Madison, WI, 53792
}

\section{Abstract}

Only a handful of the many fungal species on our planet cause infections in humans. Despite many medical advances, invasive fungal infections have skyrocketed in recent years and pose a growing health problem in both immune-competent and -deficient hosts. Recent strides in our understanding of fungal immunity have raised the prospect that vaccines against fungi can be developed that are effective, safe and able to elicit lasting immunity even in immune deficient individuals. We discuss progress in vaccine development and understanding mechanisms of protection against fungi including in patients with impaired $\mathrm{CD} 4^{+} \mathrm{T}$-cell immunity.

\section{Keywords}

Fungi; yeast; vaccines; immunity

\section{INTRODUCTION}

Vaccines have been hailed as one of the greatest achievements in the public health during the past century. The global eradication of Smallpox virus in humans and Rinderpest virus in animals, along with the near eradication or successful prevention of other viral or bacterial infections, support this claim. Yet, the development of safe and efficacious vaccines has been a major hurdle for other infectious agents including fungi, partly due to of our lack of knowledge about the mechanisms that underpin protective immunity. Recent insights on immunity against fungal infections have yielded candidate vaccines with promising potency in animal models that may be translated for prevention of infections in humans [1,2].

\footnotetext{
C 2014 Elsevier Ltd. All rights reserved.

Reprints and correspondence to: Som Nanjappa or Bruce Klein, University of Wisconsin, Microbial Sciences Building, 1550 Linden Drive, Madison, WI, 53706 Telephone: 608-263-6203.sgnanjappa@ pediatrics.wisc.edu; bsklein@wisc.edu.

Publisher's Disclaimer: This is a PDF file of an unedited manuscript that has been accepted for publication. As a service to our customers we are providing this early version of the manuscript. The manuscript will undergo copyediting, typesetting, and review of the resulting proof before it is published in its final citable form. Please note that during the production process errors may be discovered which could affect the content, and all legal disclaimers that apply to the journal pertain.
} 
Despite hundreds of thousands of fungal species, only a few cause disease in humans. The most common fungi that infect humans are Candida spp., Aspergillus fumigatus, Cryptococcus neoformans, Pneumocystis jiroveci (carinii) and the thermally dimorphic fungi e.g. Histoplasma capsulatum, Blastomyces dermatitidis, Coccidiodes posadasii, Penicillium marneffei and Paracoccidiodes brasiliensis [3]. Humans commonly encounter fungi by inhalation of spores or by invasion through a breach in anatomical barriers, as with nosocomial fungal infections. The spectrum of fungal infections is broad and includes selflimiting cutaneous infection, acute pneumonia and widely disseminated, systemic infections. Opportunistic fungal infections with low-virulence pathogens are distinct in that they usually occur in "high risk" populations of patients: suppressed immunity due to treatment of cancer, organ transplants, or autoimmune disease; breached anatomic barriers after prosthetic surgery or invasive catheter placement; broad spectrum antibiotics that alter normal flora; and those with HIV or other immune deficiencies. While the endemic mycoses caused by dimorphic fungi can produce disseminated infection in these at risk groups, these pathogens are best known for causing infections in otherwise healthy hosts that live in the endemic zones.

$\mathrm{CD}^{+} \mathrm{T}$ cells play a major role in mediating resistance to fungal infection, hence the higher incidences in individuals with reduced $\mathrm{CD} 4^{+} \mathrm{T}$ cell numbers or function. $\mathrm{CD} 4^{+} \mathrm{T}$ cells confer resistance through secretion of T-helper (Th) 1 or Th17 cytokines such as IFN $\gamma$, TNFa, GM-CSF and IL-17A, respectively, which activate neutrophils, macrophages, dendritic cells and inflammatory monocytes for fungal killing and clearance; and by activating B cells to secrete protective antibodies [1,2]. IL-17 is integral for protection against a number of fungal pathogens, although its role is debated in animal models of aspergillosis and gastric candidiasis, where it can exacerbate disease [1,2,4-8]. Fungal vaccine candidates have focused mainly on stimulating $\mathrm{CD} 4^{+} \mathrm{T}$ cells and $\mathrm{B}$ cells and protection mediated by these defenses. A growing appreciation for the role of $\mathrm{CD} 8^{+} \mathrm{T}$ cells in anti-fungal immunity has offered an avenue to exploit alternative vaccine strategies designed for individuals with $\mathrm{CD} 4{ }^{+} \mathrm{T}$ cell lymphopenia syndromes like in AIDS. In this review, we address recent developments in fungal vaccines and discuss new insights about immune mechanisms that govern protection against fungi, including the under appreciated role of $\mathrm{CD}^{+} \mathrm{T}$ cell immunity against fungal infections.

\section{Vaccines against the fungi}

In recent years, a number of fungal vaccine candidates have been reported, refined and tested in animal models for their safety, immunogenicity and efficacy and at least two of them are now under study in human clinical trials. Many are listed in Table 1; several are emphasized below.

Vaccination against Candida—Candida albicans is most commonly found as a commensal on mucosal surfaces in the gut and vagina. However, C. albicans can cause mucocutaneous infections of the oropharynx, skin, nails and vagina; and produce lifethreatening bloodstream infections in immune suppressed hosts or when anatomical barriers are breached. The major risk factors for invasive candidiasis are medical interventions such those as following transplantation of solid organs, hemotopoietic stem cells or bone marrow; 
surgeries; and use of IV catheters. Candida albicans is most common in these settings although non-albicans Candida sp. such as C. glabrata have recently emerged [9].

Vaccine immunity against Candida infection in animal models is mediated by Th1 and Th17 cells, and by antibodies (Table 1). An investigational candidate vaccine containing rAls3p-N (NDV-3), which is directed against Candida and also S. aureus, has been tested for safety and immunogenicity in volunteers in a Phase I clinical trial, and efficacy studies are now being planned. Another candidate vaccine containing rSap2p was found to be well tolerated and effective at low doses in inducing specific antibodies and B cell memory in women with recurrent vulvovaginitis in a European clinical trial [10].

Vaccination against pulmonary mycoses-Pulmonary mycoses are acquired by inhalation of spores or mycelial fragments. Clinical manifestations vary from mild, selflimiting lung infections to fulminant ARDS, or life-threatening, disseminated infections during immunosuppression.

Aspergillus sp. can cause acute and chronic pneumonia, allergic bronchopulmonary aspergillosis, aspergilloma and invasive aspergillosis. Experimental vaccines have been shown to mediate protection by inducing strong Th1 responses (Table 1). Th2 responses have been associated with allergic reactions and defective fungal clearance, while Th17 responses during primary infection can be pathological. Immunity against Aspergillus and other fungi has been observed after vaccination with heat-killed Saccharomyces. Similarly, Crf1 protein induced Aspergillus specific $\mathrm{CD}^{+}{ }^{+} \mathrm{T}$-cell responses in healthy individuals [11], and vaccination with the same Crflp mediated cross-protection against candidiasis and aspergillosis [12].

Cryptococcus neoformans can cause life threatening pulmonary and CNS infections in patients with severely compromised immunity such as in AIDS, whereas C. gatti infection has recently emerged as a pathogen in previously healthy individuals. Cryptococcus is a leading cause of meningitis in some parts of the world (see below). Candidate vaccines comprising Glucoronoxylomannan (GXM), peptide mimotopes of GXM, cell filtrate antigens (Cnef) and protein-conjugated laminaran were shown to mediate protection by inducing antibodies and promoting Th1 cell responses (Table 1). Mannosylation of protein antigen has been shown to greatly promote anti-cryptococcal Th1 and $\mathrm{CD} 8^{+} \mathrm{T}$ cell responses and protective immunity [13].

Pneumocystis pneumonia is generally restricted to immunocompromised patients and carries a high mortality rate. Antibody and $\mathrm{CD} 8^{+} \mathrm{T}$ cells have been shown to play a role in vaccineinduced resistance to Pneumocystis mediated by Kexin vaccination in immune deficient mice [14]. DNA vaccines have shown some promise in murine models, with protection likely mediated by antibodies and Th1 cell responses $[15,16]$.

Thermally dimorphic fungi grow as sporulating molds in soil. After spores or mycelial fragments are inhaled, they convert to parasitic yeast or spherules that initiate infection and can disseminate. An attenuated live vaccine lacking the virulence factor BAD-1 was developed against blastomycosis; vaccine immunity is primarily mediated by Th1 and Th17 
cells, but not by antibodies [2]. Protective $\mathrm{CD} 4^{+} \mathrm{T}$ cells raised with that vaccine have been found to mediate broad protection against blastomycosis, as well as histoplasmosis and coccidioidomycosis, suggesting a conserved protective antigen and the prospect of a "panfungal" vaccine [6]. Th17 cells were necessary and sufficient in mediating vaccine immunity to these mycoses, supporting growing evidence that IL-17A confers resistance to fungal infections.

Vaccination with live Histoplasma confers protection against lethal pulmonary infection in a murine model [6]. Vaccination with rHSP60 is also capable of eliciting protective immunity via $\mathrm{CD} 4^{+} \mathrm{T}$-cells and the action of IFN- $\gamma$ [17]. A killed spherule vaccine against coccidioidomycosis failed to provide protection in humans during a Phase 3 clinical trial, but recent work using recombinant Ag2/PRA-CSA as a vaccine in nonhuman primates has shown promise [18]. Likewise, vaccination of mice against Coccidioides using multiple Tcell epitopes induced resistance, which was linked to induction of Th1 and Th17 cytokines [19]. Several protein-based vaccine candidates have been shown to provide a therapeutic immunity against paracoccidioidomycosis where Th1 and antibodies played a protective role [20-22].

\section{CD8+ T-cell immunity against fungal infections}

Most of the existing fungal vaccine candidates have not been studied for immune stimulation of $\mathrm{CD}^{+} \mathrm{T}$ cells in $\mathrm{CD} 4^{+} \mathrm{T}$-cell deficient hosts. Fungal infections in $\mathrm{CD} 4^{+} \mathrm{T}$ cell lymphopenic patients have risen at alarming rates due to the HIV pandemic, and despite antifungal therapy, they can carry a mortality rate of 5\%-70\% depending on the type of fungal infection [23-25]. In a recent survey, cryptococcosis in sub-Saharan Africa produced mortality rates of 50-70\%, even surpassing deaths caused by tuberculosis, another major opportunistic infection associated with AIDS [24]. Even though opportunistic fungi frequently emerge in HIV patients, primary systemic fungal pathogens also cause lifethreatening disease when effector $\mathrm{CD}^{+}{ }^{+} \mathrm{T}$ cells are absent or functionally impaired, signifying the need for alternative strategies of control and prevention in immune compromised patients $[26,27]$. Hence, understanding the role of $\mathrm{CD}^{+} \mathrm{T}$ cell immunity against fungal infections may aid in the development of fungal vaccines tailored to such patients. Several studies have documented protective immunity mediated by $\mathrm{CD}^{+} \mathrm{T}$ cells against fungal pathogens (Table 2 ), although $\mathrm{CD}^{+} \mathrm{T}$ cells usually exert a more prominent role in immune competent hosts. Even if vaccine-induced immunity is "unnatural", and not otherwise evident in immunologically intact hosts, perhaps the development of fungal vaccines tailored to augment memory $\mathrm{CD}^{+} \mathrm{T}$ cell responses may help combat mycosesrelated mortality in at risk individuals. Below, we address this potential alternative avenue in the development of fungal vaccines for $\mathrm{CD}^{+} \mathrm{T}$-cell lymphopenic patients.

Protective anti-fungal $\mathrm{CD}^{+} \mathrm{T}$ cell responses and resistance can be elicited in the absence of obvious $\mathrm{CD}^{+} \mathrm{T}$ cell help [4,28-33]. Anti-fungal $\mathrm{CD}^{+} \mathrm{T}$-cell responses are generally elicited by cross-presentation and MHC class I loading of fungal peptides. Cross-priming of $\mathrm{CD}^{+} \mathrm{T}$ cells can be influenced by host immune status and the nature of the vaccine. In a model of Aspergillus vaccine immunity, cross-priming of $\mathrm{CD}^{+} \mathrm{T}$ cells required endosome alkalization and autophagy in dendritic cells, which was defective in CGD mice, yet priming 
of $\mathrm{CD} 4^{+} \mathrm{T}$ cells by soluble antigen in these mice remained intact, involving distinct and preserved pathways [34].

Anti-fungal immunity in the absence of $\mathrm{CD}^{+} \mathrm{T}$ cell immunity is mediated by $\mathrm{Tc} 1$ (type 1 ) cells that secrete IFN $\gamma, \mathrm{TNFa}$, and GM-CSF, as well as by the cytotoxic factors perforin, granulysin and granzyme $\mathrm{K}$, suggesting indirect killing (pro-inflammatory cytokine activation of other cells) and direct killing mechanisms. However, like the prominent role played by Th17 cells in intact hosts, recent studies have shown that anti-fungal immunity also can be mediated by $\mathrm{Tc} 17$ cells (IL-17A producing $\mathrm{CD} 8^{+} \mathrm{T}$ cells) in $\mathrm{CD} 4^{+} \mathrm{T}$ cell deficient hosts $[4,35]$. For example, in a model of blastomycosis, Tc17 cells were required for vaccine immunity in the absence of $\mathrm{CD}^{+}{ }^{+} \mathrm{T}$ cells [35]. Similar to other models, IL-12 was involved in Tc1 priming whereas IL- 6 and likely IL-1 and IL-23 were required for Tc17 cell responses [35,36] (Figure 1). Tc17 cell effectors selectively expressed chemokine receptor CCR6, whereas Tc1 cells preferentially expressed CXCR3 and these receptors were required for recruitment into the lungs during pulmonary infection $[35,37,38]$. In contrast to Tc1 cells, Tc17 cells were mainly CD62 $\mathrm{L}^{\mathrm{lo}}$ and CD27 ${ }^{\text {int/lo }}$ suggesting an effector memory phenotype [35]. However, like Tc1 cells, Tc17 cells were TCF- $1^{\text {hi }}$ and KLRG- $1^{\text {lo }}$ indicating their capacity for long-term survival [35,37]. In view of the growing evidence for IL-17 producing cells in anti-fungal immunity $[1,2,6]$, it may not be surprising that Tc17 cells can mediate control of fungal infections in immune deficient hosts.

Memory CD8 ${ }^{+}$T cell immunity-Immunological memory is the hallmark of vaccination. Pathogen-specific memory T and B cells can persist in the absence of immunogen and are able to mount rapid anamnestic responses and clear infection following re-exposure, thus explaining the effect of vaccination. Since many fungal infections occur in the setting of immune deficiency where $\mathrm{CD} 4^{+} \mathrm{T}$ cells may be absent, reduced, or dysfunctional, it becomes critical to understand the limits of memory maintenance under these unusual circumstances.

A typical $\mathrm{CD} 8^{+} \mathrm{T}$ cell response to an immunogen involves differentiation and rapid proliferation during an expansion phase, apoptosis of $~ 90 \%$ effectors during a contraction phase, and differentiation of the remaining $\sim 10 \%$ of memory precursors into long-term memory cells during the memory phase. $\mathrm{CD}^{+} \mathrm{T}$ cells have been shown to foster the normal memory homeostasis of $\mathrm{CD}^{+} \mathrm{T}$ cells in models of viral and bacterial infection. By contrast, models of fungal infection have suggested that $\mathrm{CD} 4^{+} \mathrm{T}$ cells may not be required for generating and maintaining antifungal $\mathrm{CD} 8^{+} \mathrm{T}$ cell immunity. In a model of vaccine immunity against blastomycosis [37], anti-fungal memory $\mathrm{CD}^{+} \mathrm{T}$ cells were generated in the absence of $\mathrm{CD}^{+} \mathrm{T}$-cell help, and maintained without reduced quantity or function in the absence of the antigen, suggesting a unique priming environment that facilitates their longterm survival, and a distinct effector cell profile that is different from that following antiviral or anti-bacterial immunization.

Why might anti-fungal $\mathrm{CD} 8^{+} \mathrm{T}$ cell responses be different? First, the models used have included live attenuated fungal strains, which may generate a unique inflammatory milieu that is different from subunit/recombinant/DNA vaccines. Second, whole cell-based vaccines promote cross-presentation, which, along with an appropriate inflammatory milieu, 
can give rise to a broad repertoire of $\mathrm{CD}^{+} \mathrm{T}$ cell responses. Third, this broad repertoire of $\mathrm{CD}^{+} \mathrm{T}$ cell responses may be less prone to exhaustion or terminal differentiation. Fourth, $\mathrm{CD}^{+} \mathrm{T}$ cell responses in these models arise in a setting that gives rise to multifunctional cytokine profiles, including the production of IL-2, which is known to promote and help memory cell homeostasis. Fifth, the ligands that are present in whole cell-based fungal vaccines have been associated with a molecular signature that portends memory cell homeostasis. Thus, for individual fungal infections, understanding the mechanisms of immunity and the requirement for multiple signaling pathways engaged by whole cell vaccines will pave the way to robust immunization strategies or underscore the need for suitable adjuvants that target these pathways.

However, it is possible that eliciting memory responses against eukaryotic pathogens like fungi may be fundamentally different than that for viruses and bacteria. The existence of memory Th17 has been documented in mice and humans, but the long-term survival of bona fide Th17 cells has been debated [39-42]. In a murine model of vaccine-induced immunity to blastomycosis in CD4-deficient hosts, anti-fungal effector Tc17 cells persisted over 2 months and portrayed a molecular signature that portended their long-term survival, albeit their long-term fate and plasticity remain be determined [35]. Unlike memory Th1 and Tc1 cells whose homeostasis is chiefly regulated by the cytokines IL-7 and IL-15, the requirements for Th17/Tc17 memory homeostasis might be complex and regulated differently [41].

\section{Conclusions}

Anti-fungal memory $\mathrm{CD}^{+}$cells have been elicited mainly with experimental vaccines that are comprised of live attenuated strains, which are unfeasible in the patients with suppressed immunity, including $\mathrm{CD}^{+}{ }^{+}$lymphopenia. Although subunit recombinant vaccines are preferable in these circumstances, few if any suitable fungal antigens have been identified for $\mathrm{CD}^{+} \mathrm{T}$ cells. Until protective $\mathrm{CD}^{+} \mathrm{T}$ cell antigens are identified, it may be worth considering whole cell-based vaccines such as with the nonreplicating sporozoite vaccine against malaria [43]. However, strategies for bolstering the long-term maintenance of protective immunity will need to be developed using killed or inactivated fungi [44].

\section{References}

1. Romani L. Immunity to fungal infections. Nat Rev Immunol. 2011; 11:275-288. [PubMed: 21394104]

2. Wuthrich M, Deepe GS Jr, Klein B. Adaptive immunity to fungi. Annu Rev Immunol. 2012; 30:115-148. [PubMed: 22224780]

3. Pfaller MA, Diekema DJ. Epidemiology of invasive mycoses in North America. Crit Rev Microbiol. 2010; 36:1-53. [PubMed: 20088682]

-4. Hernandez-Santos N, Huppler AR, Peterson AC, Khader SA, McKenna KC, Gaffen SL. Th17 cells confer long-term adaptive immunity to oral mucosal Candida albicans infections. Mucosal Immunol. 2013; 6:900-910. This study gives the evidence that Tc17 cells participate in fungal control during experimental oropharyngeal candidiasis. [PubMed: 23250275]

5. Ifrim DC, Bain JM, Reid DM, Oosting M, Verschueren I, Gow NA, van Krieken JH, Brown GD, Kullberg BJ, Joosten LA, et al. The role of Dectin-2 for host defense against systemic infection with Candida glabrata. Infect Immun. 2013 
••6. Wuthrich M, Gern B, Hung CY, Ersland K, Rocco N, Pick-Jacobs J, Galles K, Filutowicz H, Warner T, Evans M, et al. Vaccine-induced protection against 3 systemic mycoses endemic to North America requires Th17 cells in mice. J Clin Invest. 2011; 121:554-568. This study illustrates that Th17 cells are necessary and sufficient to mediate vaccine induced protection against 3 systemic mycoses. [PubMed: 21206087]

7. Zelante T, De Luca A, Bonifazi P, Montagnoli C, Bozza S, Moretti S, Belladonna ML, Vacca C, Conte C, Mosci P, et al. IL-23 and the Th17 pathway promote inflammation and impair antifungal immune resistance. Eur J Immunol. 2007; 37:2695-2706. [PubMed: 17899546]

8. Hung CY, Gonzalez A, Wuthrich M, Klein BS, Cole GT. Vaccine immunity to coccidioidomycosis occurs by early activation of three signal pathways of T helper cell response (Th1, Th2, and Th17). Infect Immun. 2011; 79:4511-4522. [PubMed: 21859851]

9. Papon N, Courdavault V, Clastre M, Bennett RJ. Emerging and emerged pathogenic Candida species: beyond the Candida albicans paradigm. PLoS Pathog. 2013; 9:e1003550. [PubMed: 24086128]

10. Edwards JE Jr. Fungal cell wall vaccines: an update. J Med Microbiol. 2012; 61:895-903. [PubMed: 22267544]

11. Jolink H, Meijssen IC, Hagedoorn RS, Arentshorst M, Drijfhout JW, Mulder A, Claas FH, van Dissel JT, Falkenburg JH, Heemskerk MH. Characterization of the T-cell-mediated immune response against the Aspergillus fumigatus proteins Crf1 and catalase 1 in healthy individuals. $\mathrm{J}$ Infect Dis. 2013; 208:847-856. [PubMed: 23698813]

••12. Stuehler C, Khanna N, Bozza S, Zelante T, Moretti S, Kruhm M, Lurati S, Conrad B, Worschech E, Stevanovic S, et al. Cross-protective TH1 immunity against Aspergillus fumigatus and Candida albicans. Blood. 2011; 117:5881-5891. This study provides evidence for the existence of human T cells against Crf1 protein that mediate protection against multiple, distantly related pathogenic fungi. [PubMed: 21441461]

13. Luong M, Lam JS, Chen J, Levitz SM. Effects of fungal N- and O-linked mannosylation on the immunogenicity of model vaccines. Vaccine. 2007; 25:4340-4344. [PubMed: 17412460]

14. Zheng M, Ramsay AJ, Robichaux MB, Norris KA, Kliment C, Crowe C, Rapaka RR, Steele C, McAllister F, Shellito JE, et al. CD4+ T cell-independent DNA vaccination against opportunistic infections. The Journal of clinical investigation. 2005; 115:3536-3544. [PubMed: 16308571]

15. Feng Y, Guo S, Jiang T, Han X, Liu P, Wu T, Luo Y. Active immunization against Pneumocystis carinii with p55-v3 DNA vaccine in rats. Can J Microbiol. 2011; 57:375-381. [PubMed: 21529125]

16. Duan YN, Yi LH, Chen JL, Zhu DD, Wang JX, Feng JR, Qin YW, Zhu Y. Protective effect of DNA vaccine with the gene encoding $55 \mathrm{kDa}$ antigen fragment against Pneumocystis carinii in mice. Asian Pac J Trop Med. 2011; 4:353-356. [PubMed: 21771675]

17. Scheckelhoff M, Deepe GS Jr. The protective immune response to heat shock protein 60 of Histoplasma capsulatum is mediated by a subset of V beta 8.1/8. 2+ T cells. J Immunol. 2002; 169:5818-5826. [PubMed: 12421963]

18. Johnson SM, Lerche NW, Pappagianis D, Yee JL, Galgiani JN, Hector RF. Safety, antigenicity, and efficacy of a recombinant coccidioidomycosis vaccine in cynomolgus macaques (Macaca fascicularis). Ann N Y Acad Sci. 2007; 1111:290-300. [PubMed: 17347333]

•19. Hurtgen BJ, Hung CY, Ostroff GR, Levitz SM, Cole GT. Construction and evaluation of a novel recombinant T cell epitope-based vaccine against Coccidioidomycosis. Infect Immun. 2012; 80:3960-3974. First report of a T-cell epitope based vaccine candidate against cocccidiodomycosis, and the potential value of glucan particles as an adjuvant and delivery vehicle. [PubMed: 22949556]

20. Mayorga O, Munoz JE, Lincopan N, Teixeira AF, Ferreira LC, Travassos LR, Taborda CP. The role of adjuvants in therapeutic protection against paracoccidioidomycosis after immunization with the P10 peptide. Front Microbiol. 2012; 3:154. [PubMed: 22586420]

21. Fernandes VC, Martins EM, Boeloni JN, Coitinho JB, Serakides R, Goes AM. Additive effect of $\mathrm{rPb} 27$ immunization and chemotherapy in experimental paracoccidioidomycosis. PLoS One. 2011; 6:e17885. [PubMed: 21423771] 
22. de Bastos Ascenco Soares R, Gomez FJ, de Almeida Soares CM, Deepe GS Jr. Vaccination with heat shock protein 60 induces a protective immune response against experimental Paracoccidioides brasiliensis pulmonary infection. Infect Immun. 2008; 76:4214-4221. [PubMed: 18625731]

23. Miller RF, Huang L, Walzer PD. Pneumocystis pneumonia associated with human immunodeficiency virus. Clin Chest Med. 2013; 34:229-241. [PubMed: 23702173]

24. Park BJ, Wannemuehler KA, Marston BJ, Govender N, Pappas PG, Chiller TM. Estimation of the current global burden of cryptococcal meningitis among persons living with HIV/AIDS. AIDS. 2009; 23:525-530. [PubMed: 19182676]

25. Nacher M, Adenis A, Mc Donald S, Do Socorro Mendonca Gomes M, Singh S, Lopes Lima I, Malcher Leite R, Hermelijn S, Wongsokarijo M, Van Eer M, et al. Disseminated Histoplasmosis in HIV-Infected Patients in South America: A Neglected Killer Continues on Its Rampage. PLoS Negl Trop Dis. 2013; 7:e2319. [PubMed: 24278485]

26. Pupaibool J, Limper AH. Other HIV-associated pneumonias. Clin Chest Med. 2013; 34:243-254. [PubMed: 23702174]

-27. Kenyon C, Bonorchis K, Corcoran C, Meintjes G, Locketz M, Lehloenya R, Vismer HF, Naicker $\mathrm{P}$, Prozesky H, van Wyk M, et al. A dimorphic fungus causing disseminated infection in South Africa. N Engl J Med. 2013; 369:1416-1424. This report describes a new species of dimorphic fungal pathogen in $\mathrm{HIV}^{+}$patients. [PubMed: 24106934]

28. Castellino F, Germain RN. Cooperation between CD4(+) and CD8(+) T cells: When, where, and how. Annual Review of Immunology. 2006; 24:519-540.

29. Wuthrich M, Filutowicz HI, Warner T, Deepe GS Jr, Klein BS. Vaccine immunity to pathogenic fungi overcomes the requirement for CD4 help in exogenous antigen presentation to CD8+ T cells: implications for vaccine development in immune-deficient hosts. J Exp Med. 2003; 197:14051416. [PubMed: 12782709]

30. Lindell DM, Moore TA, McDonald RA, Toews GB, Huffnagle GB. Generation of antifungal effector CD8+ T cells in the absence of CD4+ T cells during Cryptococcus neoformans infection. J Immunol. 2005; 174:7920-7928. [PubMed: 15944298]

31. Kolls JK, Habetz S, Shean MK, Vazquez C, Brown JA, Lei D, Schwarzenberger P, Ye P, Nelson $\mathrm{S}$, Summer WR, et al. IFN-gamma and CD8+ T cells restore host defenses against Pneumocystis carinii in mice depleted of CD4+ T cells. J Immunol. 1999; 162:2890-2894. [PubMed: 10072538]

32. Fierer J, Waters C, Walls L. Both CD4+ and CD8+ T cells can mediate vaccine-induced protection against Coccidioides immitis infection in mice. J Infect Dis. 2006; 193:1323-1331. [PubMed: 16586371]

33. Chiarella AP, Arruda C, Pina A, Costa TA, Ferreira RC, Calich VL. The relative importance of CD4+ and CD8+T cells in immunity to pulmonary paracoccidioidomycosis. Microbes Infect. 2007; 9:1078-1088. [PubMed: 17692551]

••34. De Luca A, Iannitti RG, Bozza S, Beau R, Casagrande A, D’Angelo C, Moretti S, Cunha C, Giovannini G, Massi-Benedetti C, et al. CD4(+) T cell vaccination overcomes defective crosspresentation of fungal antigens in a mouse model of chronic granulomatous disease. J Clin Invest. 2012; 122:1816-1831. This study describes defective cross-priming of CD8 ${ }^{+} \mathrm{T}$ cells using conidia to immunize mice in a model mimicking chronic granulomatous disease, and elucidates the mechanistic underpinning of the defect, despite intact priming of $\mathrm{CD}^{+}{ }^{+} \mathrm{T}$ cells with soluble antigen. [PubMed: 22523066]

••35. Nanjappa SG, Heninger E, Wuthrich M, Gasper DJ, Klein BS. Tc17 cells mediate vaccine immunity against lethal fungal pneumonia in immune deficient hosts lacking CD4+ T cells. PLoS Pathog. 2012; 8:e1002771. This study gives evidence of the requirement for Tc17 cells in vaccine immunity and further implies their propensity for long-term memory. [PubMed: 22829762]

36. Wuthrich M, Warner T, Klein BS. IL-12 is required for induction but not maintenance of protective, memory responses to Blastomyces dermatitidis: implications for vaccine development in immune-deficient hosts. J Immunol. 2005; 175:5288-5297. [PubMed: 16210634]

••37. Nanjappa SG, Heninger E, Wuthrich M, Sullivan T, Klein B. Protective antifungal memory CD8(+) T cells are maintained in the absence of CD4(+) T cell help and cognate antigen in mice. J Clin Invest. 2012; 122:987-999. This study uses rigorous methods to demonstrate the 
dispensability of $\mathrm{CD} 4^{+} \mathrm{T}$ cell help for the maintenance of protective anti-fungal $\mathrm{CD} 8^{+} \mathrm{T}$ cells. [PubMed: 22354169]

38. McAllister F, Ruan S, Steele C, Zheng M, McKinley L, Ulrich L, Marrero L, Shellito JE, Kolls JK. CXCR3 and IFN protein-10 in Pneumocystis pneumonia. J Immunol. 2006; 177:1846-1854. [PubMed: 16849496]

•39. Pepper M, Linehan JL, Pagan AJ, Zell T, Dileepan T, Cleary PP, Jenkins MK. Different routes of bacterial infection induce long-lived TH1 memory cells and short-lived TH17 cells. Nat Immunol. 2010; 11:83-89. This is the first report that Th17 may not become memory cells. [PubMed: 19935657]

••40. Muranski P, Borman ZA, Kerkar SP, Klebanoff CA, Ji Y, Sanchez-Perez L, Sukumar M, Reger $\mathrm{RN}, \mathrm{Yu} \mathrm{Z}$, Kern SJ, et al. Th17 cells are long lived and retain a stem cell-like molecular signature. Immunity. 2011; 35:972-985. This is the first evidence that Th17 cells bear the features of stem-cells and survive as memory cells eventhough they converted into Th1 cells. [PubMed: 22177921]

•41. Haines CJ, Chen Y, Blumenschein WM, Jain R, Chang C, Joyce-Shaikh B, Porth K, Boniface K, Mattson J, Basham B, et al. Autoimmune memory T helper 17 cell function and expansion are dependent on interleukin-23. Cell Rep. 2013; 3:1378-1388. This study gives evidence that IL-23 signaling is required for memory Th17 responses. [PubMed: 23623497]

42. Nakayamada S, Takahashi H, Kanno Y, O’Shea JJ. Helper T cell diversity and plasticity. Curr Opin Immunol. 2012; 24:297-302. [PubMed: 22341735]

• 43. Seder RA, Chang LJ, Enama ME, Zephir KL, Sarwar UN, Gordon IJ, Holman LA, James ER, Billingsley PF, Gunasekera A, et al. Protection against malaria by intravenous immunization with a nonreplicating sporozoite vaccine. Science. 2013; 341:1359-1365. The report of success of a whole cell-based vaccine against malaria, which is given intravenously. [PubMed: 23929949]

44. Lauvau G, Vijh S, Kong P, Horng T, Kerksiek K, Serbina N, Tuma RA, Pamer EG. Priming of memory but not effector CD8 T cells by a killed bacterial vaccine. Science. 2001; 294:1735-1739. [PubMed: 11721060]

45. Bozza S, Gaziano R, Lipford GB, Montagnoli C, Bacci A, Di Francesco P, Kurup VP, Wagner H, Romani L. Vaccination of mice against invasive aspergillosis with recombinant Aspergillus proteins and CpG oligodeoxynucleotides as adjuvants. Microbes Infect. 2002; 4:1281-1290. [PubMed: 12443892]

46. Ito JI, Lyons JM, Hong TB, Tamae D, Liu YK, Wilczynski SP, Kalkum M. Vaccinations with recombinant variants of Aspergillus fumigatus allergen Asp f 3 protect mice against invasive aspergillosis. Infect Immun. 2006; 74:5075-5084. [PubMed: 16926399]

47. Bozza S, Clavaud C, Giovannini G, Fontaine T, Beauvais A, Sarfati J, D’Angelo C, Perruccio K, Bonifazi P, Zagarella S, et al. Immune sensing of Aspergillus fumigatus proteins, glycolipids, and polysaccharides and the impact on Th immunity and vaccination. J Immunol. 2009; 183:24072414. [PubMed: 19625642]

48. Cole GT, Hurtgen BJ, Hung CY. Progress Toward a Human Vaccine Against Coccidioidomycosis. Curr Fungal Infect Rep. 2012; 6:235-244. [PubMed: 23585916]

49. Stevens DA, Clemons KV, Liu M. Developing a vaccine against aspergillosis. Med Mycol. 2011; 49 (Suppl 1):S170-176. [PubMed: 20608783]

•50. Lin L, Ibrahim AS, Xu X, Farber JM, Avanesian V, Baquir B, Fu Y, French SW, Edwards JE Jr, Spellberg B. Th1-Th17 cells mediate protective adaptive immunity against Staphylococcus aureus and Candida albicans infection in mice. PLoS Pathog. 2009; 5:e1000703. This report establishes the surprising observation of cross protection against Candida and Staph aureus mediated by vaccination with ALS3, and defines the contributions of T cells, especially those elaborating IL-17. [PubMed: 20041174]

51. Luo G, Ibrahim AS, French SW, Edwards JE Jr, Fu Y. Active and passive immunization with rHyr1p-N protects mice against hematogenously disseminated candidiasis. PLoS One. 2011; 6:e25909. [PubMed: 22028796]

52. Sandini S, La Valle R, Deaglio S, Malavasi F, Cassone A, De Bernardis F. A highly immunogenic recombinant and truncated protein of the secreted aspartic proteases family (rSap2t) of Candida albicans as a mucosal anticandidal vaccine. FEMS Immunol Med Microbiol. 2011; 62:215-224. [PubMed: 21535228] 
53. Bromuro C, Romano M, Chiani P, Berti F, Tontini M, Proietti D, Mori E, Torosantucci A, Costantino P, Rappuoli R, et al. Beta-glucan-CRM197 conjugates as candidates antifungal vaccines. Vaccine. 2010; 28:2615-2623. [PubMed: 20096763]

54. Rachini A, Pietrella D, Lupo P, Torosantucci A, Chiani P, Bromuro C, Proietti C, Bistoni F, Cassone A, Vecchiarelli A. An anti-beta-glucan monoclonal antibody inhibits growth and capsule formation of Cryptococcus neoformans in vitro and exerts therapeutic, anticryptococcal activity in vivo. Infect Immun. 2007; 75:5085-5094. [PubMed: 17606600]

55. Paulovicova E, Machova E, Tulinska J, Bystricky S. Cell and antibody mediated immunity induced by vaccination with novel Candida dubliniensis mannan immunogenic conjugate. Int Immunopharmacol. 2007; 7:1325-1333. [PubMed: 17673147]

56. Saville SP, Lazzell AL, Chaturvedi AK, Monteagudo C, Lopez-Ribot JL. Efficacy of a genetically engineered Candida albicans tet-NRG1 strain as an experimental live attenuated vaccine against hematogenously disseminated candidiasis. Clin Vaccine Immunol. 2009; 16:430-432. [PubMed: 19144791]

57. Cutler JE, Corti M, Lambert P, Ferris M, Xin H. Horizontal transmission of Candida albicans and evidence of a vaccine response in mice colonized with the fungus. PLoS One. 2011; 6:e22030. [PubMed: 21818288]

58. Tarcha EJ, Basrur V, Hung CY, Gardner MJ, Cole GT. A recombinant aspartyl protease of Coccidioides posadasii induces protection against pulmonary coccidioidomycosis in mice. Infect Immun. 2006; 74:516-527. [PubMed: 16369008]

59. Chow SK, Casadevall A. Evaluation of Cryptococcus neoformans galactoxylomannan-protein conjugate as vaccine candidate against murine cryptococcosis. Vaccine. 2011; 29:1891-1898. [PubMed: 21238568]

60. Datta K, Lees A, Pirofski LA. Therapeutic efficacy of a conjugate vaccine containing a peptide mimotope of cryptococcal capsular polysaccharide glucuronoxylomannan. Clin Vaccine Immunol. 2008; 15:1176-1187. [PubMed: 18524882]

61. Specht CA, Nong S, Dan JM, Lee CK, Levitz SM. Contribution of glycosylation to T cell responses stimulated by recombinant Cryptococcus neoformans mannoprotein. J Infect Dis. 2007; 196:796-800. [PubMed: 17674324]

62. Gomez FJ, Allendoerfer R, Deepe GS Jr. Vaccination with recombinant heat shock protein 60 from Histoplasma capsulatum protects mice against pulmonary histoplasmosis. Infect Immun. 1995; 63:2587-2595. [PubMed: 7790073]

63. Zheng M, Ramsay AJ, Robichaux MB, Norris KA, Kliment C, Crowe C, Rapaka RR, Steele C, McAllister F, Shellito JE, et al. CD4+ T cell-independent DNA vaccination against opportunistic infections. J Clin Invest. 2005; 115:3536-3544. [PubMed: 16308571]

-64. Carvalho A, De Luca A, Bozza S, Cunha C, D’Angelo C, Moretti S, Perruccio K, Iannitti RG, Fallarino F, Pierini A, et al. TLR3 essentially promotes protective class I-restricted memory CD8(+) T-cell responses to Aspergillus fumigatus in hematopoietic transplanted patients. Blood. 2012; 119:967-977. This study demonstrates how sensing of fungal RNA by cross presenting DCs is required to elicit effective memory $\mathrm{CD}^{+} \mathrm{T}$ cell responses against Aspergillus. [PubMed: 22147891]

65. Ramadan G, Davies B, Kurup VP, Keever-Taylor CA. Generation of cytotoxic T cell responses directed to human leucocyte antigen Class I restricted epitopes from the Aspergillus f16 allergen. Clin Exp Immunol. 2005; 140:81-91. [PubMed: 15762878]

•66. Sun Z, Zhu P, Li L, Wan Z, Zhao Z, Li R. Adoptive immunity mediated by HLA-A*0201 restricted Asp f16 peptides-specific CD8+ T cells against Aspergillus fumigatus infection. Eur J Clin Microbiol Infect Dis. 2012; 31:3089-3096. This reports evidence of CD8 ${ }^{+}$T-cell epitope of aspergillus showing potential protection against lethal pneumonia. [PubMed: 22696051]

•67. Potenza L, Vallerini D, Barozzi P, Riva G, Forghieri F, Beauvais A, Beau R, Candoni A, Maertens J, Rossi G, et al. Characterization of specific immune responses to different Aspergillus antigens during the course of invasive Aspergillosis in hematologic patients. PLoS One. 2013; 8:e74326. This study demonstrates the potential of T-cell based immunotherapy for invasive aspergillosis using defined peptides/proteins. [PubMed: 24023936]

68. Deepe GS Jr. Role of CD8+ T cells in host resistance to systemic infection with Histoplasma capsulatum in mice. J Immunol. 1994; 152:3491-3500. [PubMed: 8144930] 
69. Deepe GS Jr, Gibbons RS. Cellular and molecular regulation of vaccination with heat shock protein 60 from Histoplasma capsulatum. Infect Immun. 2002; 70:3759-3767. [PubMed: 12065519]

70. Zhou P, Freidag BL, Caldwell CC, Seder RA. Perforin is required for primary immunity to Histoplasma capsulatum. J Immunol. 2001; 166:1968-1974. [PubMed: 11160245]

71. Wozniak KL, Young ML, Wormley FL Jr. Protective immunity against experimental pulmonary cryptococcosis in T cell-depleted mice. Clin Vaccine Immunol. 2011; 18:717-723. [PubMed: 21450975]

72. Levitz SM, Dupont MP, Smail EH. Direct activity of human T lymphocytes and natural killer cells against Cryptococcus neoformans. Infect Immun. 1994; 62:194-202. [PubMed: 8262627]

73. Hung CY, Castro-Lopez N, Cole GT. Vaccinated C57BL/6 Mice Develop Protective and Memory T Cell Response to Coccidioides posadasii Infection in the Absence of IL-10. Infect Immun. 2013

74. Bernardino S, Pina A, Felonato M, Costa TA, Frank de Araujo E, Feriotti C, Bazan SB, Keller AC, Leite KR, Calich VL. TNF-alpha and CD8+ T cells mediate the beneficial effects of nitric oxide synthase-2 deficiency in pulmonary paracoccidioidomycosis. PLoS Negl Trop Dis. 2013; 7:e2325. [PubMed: 23936574]

75. Burlandy-Soares LC, Mamoni RL, Lyra L, Schreiber AZ, Blotta MH. Expression of activation and cytotoxic molecules by peripheral blood lymphocytes of patients with paracoccidioidomycosis. Med Mycol. 2010; 48:843-852. [PubMed: 20163282]

76. McAllister F, Steele C, Zheng M, Shellito JE, Kolls JK. In vitro effector activity of Pneumocystis murina-specific T-cytotoxic-1 CD8+ T cells: role of granulocyte-macrophage colony-stimulating factor. Infect Immun. 2005; 73:7450-7457. [PubMed: 16239546]

77. Ghaleb M, Hamad M, Abu-Elteen KH. Vaginal T lymphocyte population kinetics during experimental vaginal candidosis: evidence for a possible role of CD8+ T cells in protection against vaginal candidosis. Clin Exp Immunol. 2003; 131:26-33. [PubMed: 12519382]

•78. Quimby K, Lilly EA, Zacharek M, McNulty K, Leigh JE, Vazquez JE, Fidel PL Jr. CD8 T cells and E-cadherin in host responses against oropharyngeal candidiasis. Oral Dis. 2012; 18:153-161. This study describes the role of $\mathrm{CD}^{+}{ }^{+} \mathrm{T}$ cells during oropharyngeal candidiasis in humans. [PubMed: 21958417] 


\section{HIGHLIGHTS}

- We provide an update on understanding of the immunological mechanisms that underpin vaccine immunity to fungi.

- We describe new developments concerning vaccines against fungal pathogens in humans

- We review the prospects for harnessing protective immune responses against fungi in immune compromised hosts. 
Tc1

\section{Naïve Tc}

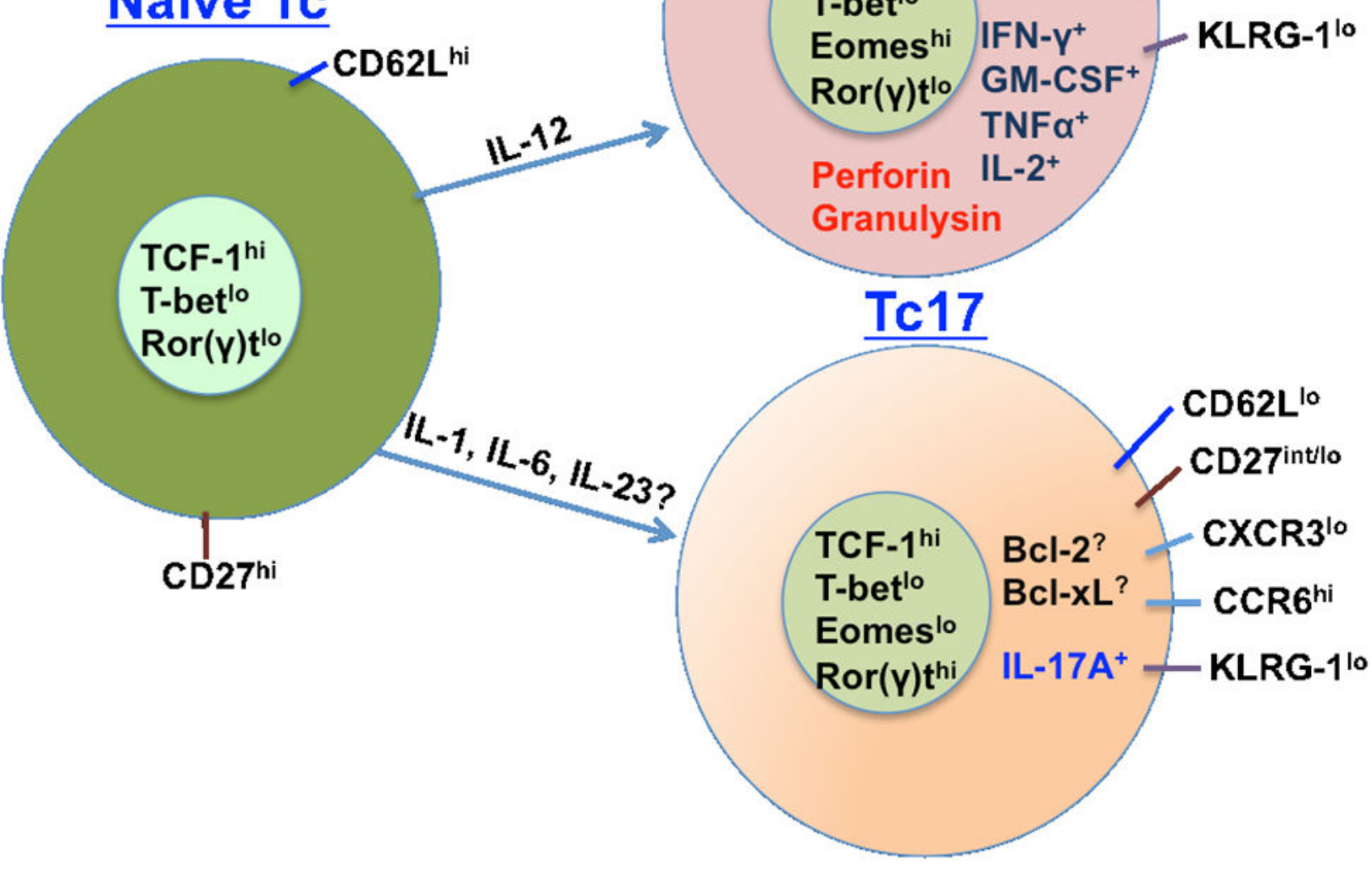

Figure 1. Development, regulation, phenotype and function of Tc1 and Tc17 cells

Schematic illustrating divergent responses of naïve cytotoxic $\mathrm{CD} 8^{+} \mathrm{T}$ cells (naïve $\mathrm{Tc}$ ) into Interleukin-12 (L-12) induced type I (Tc1) cells, and IL-6, possibly IL-1 and IL-23 induced Tc17 cells. Tc1 cells express the transcription factor T-bet (TBX21) and secrete gamma interferon (IFN- $\gamma$ ), granulocyte-monocyte colony stimulating factor (GM-CSF), tumor necrosis factor alpha (TNF-a), and interleukin-2 (IL-2). In some fungal infections, Tc1 cells express perforin and granulysin, which are required for resistance. Tc17 cells express the transcription factor $\operatorname{Ror}(\gamma) \mathrm{t}$ and secrete IL-17A. Anti-fungal Tc1 and Tc17 cells both express T cell factor 1 (TCF-1), which facilitates Wnt signaling and memory, but display different surface molecules. The roles of pro-survival proteins B cell lymphoma 2 (BCl-2) and Bcl-xL for the transition of effector into memory cells is unknown. Other markers including KLRG-1 (killer cell lectin-like receptor subfamily G member 1), Eomes (Eomesodermin), CCR6 (chemokine C-C motif receptor 6), CXCR3 (chemokine C-X-C motif receptor 3 ) are illustrated on these cells. 


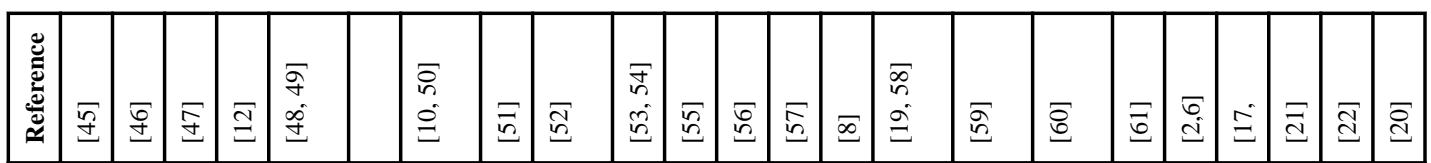

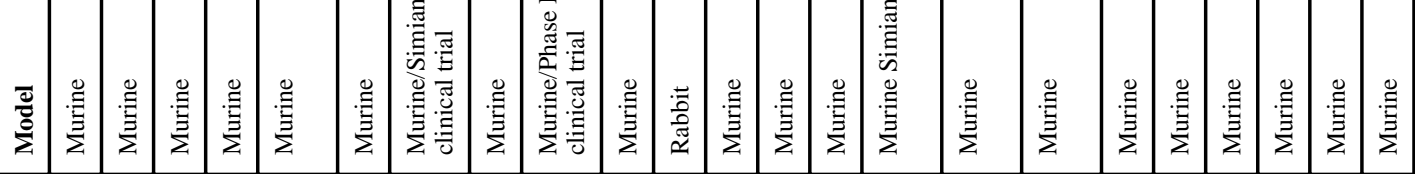

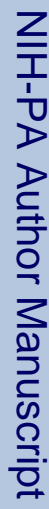

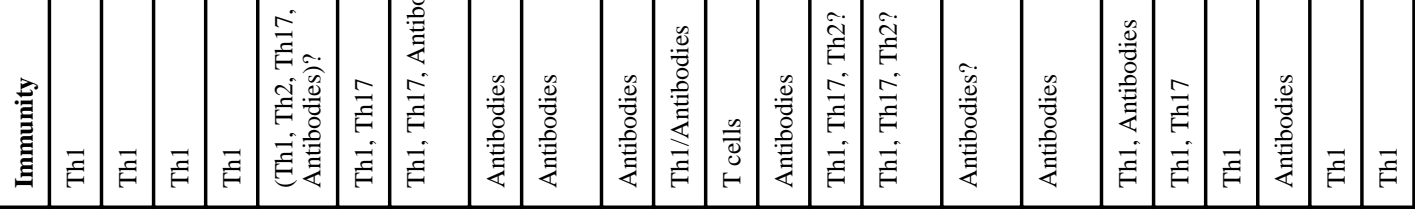




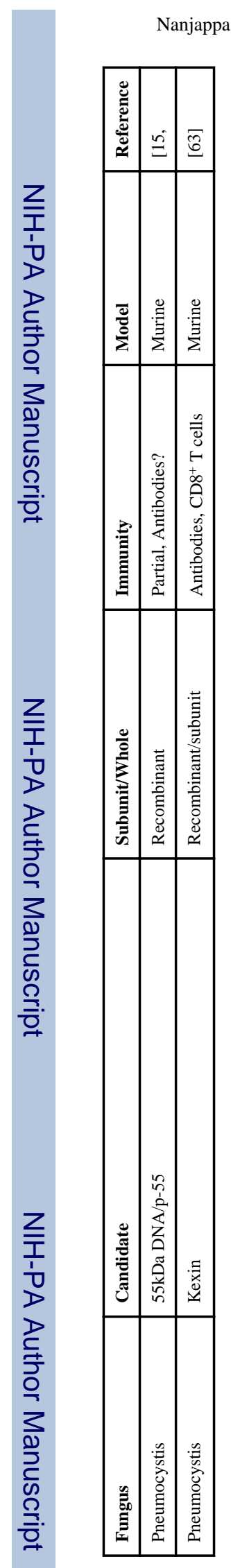

Page 15

Curr Opin Immunol. Author manuscript; available in PMC 2015 June 01. 


\begin{tabular}{|c|c|c|c|c|c|c|c|c|c|}
\hline & 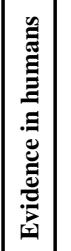 & $\begin{array}{l}E \\
0 \\
d \\
0\end{array}$ & & $\bar{\Xi}$ & & & $\bar{\Sigma}$ & & $\stackrel{\infty}{\ominus}$ \\
\hline.$\tilde{\Xi}$ & 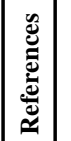 & $\vec{E}$ & $\begin{array}{l}\overline{2} \\
1 \\
0 \\
0\end{array}$ & $\mid \begin{array}{l}\vec{R} \\
\dot{0} \\
0\end{array}$ & $\begin{array}{l}\bar{\sigma} \\
\tilde{\partial} \\
\vec{d}\end{array}$ & 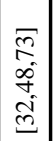 & 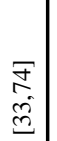 & $\stackrel{\Xi}{\Xi}$ & $\underset{\underbrace{}}{\stackrel{乛}{+}}$ \\
\hline 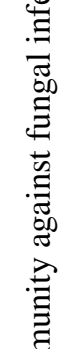 & 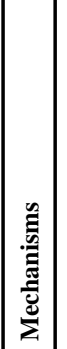 & 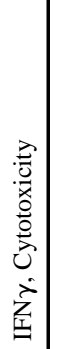 & 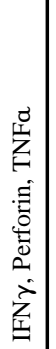 & 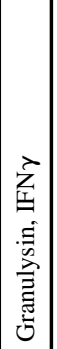 & 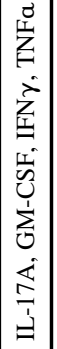 & 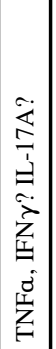 & 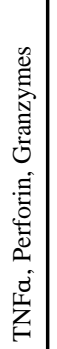 & 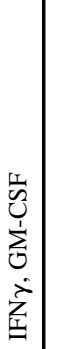 & 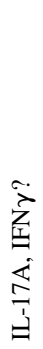 \\
\hline 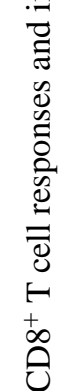 & 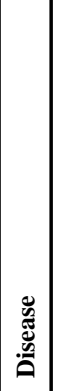 & 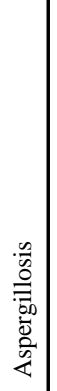 & 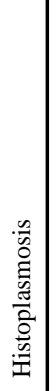 & 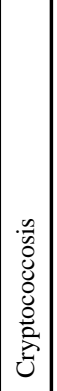 & 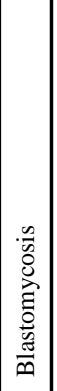 & 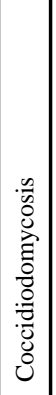 & 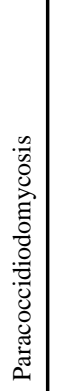 & 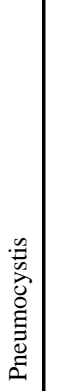 & 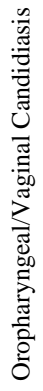 \\
\hline
\end{tabular}

Curr Opin Immunol. Author manuscript; available in PMC 2015 June 01. 